\title{
Effect of Work Teams on School Culture of The State Senior High School in DKI Jakarta
}

\author{
Venny Oktaviany ${ }^{1}$, Mukhneri Mukhtar ${ }^{2}$ and Mochamad Wahyudi ${ }^{3}$ \\ \{vennyoktaviany_mp15s3@mahasiswa.unj.ac.id ${ }^{1}$, mukhneri@unj.ac.id ${ }^{2}$,wahyudi@bsi.ac.id ${ }^{3}$ \} \\ ${ }^{1}$ Doctorate Programme of Management Education, Universitas Negeri Jakarta, Jl. \\ Rawamangun Muka, Jakarta Timur 13220, Indonesia \\ ${ }^{2}$ Management Education Departement, Universitas Negeri Jakarta, Jl. Rawamangun Muka, \\ Jakarta Timur 13220, Indonesia \\ ${ }^{3}$ Accounting Management System Departement, Universitas Bina Sarana Informatika, Jl. \\ Kamal Raya No. 18, Ring Road Barat, Cengkareng, Jakarta Barat 11730, Indonesia
}

\begin{abstract}
The objective of this research is to study the effect of work teams toward school culture of senior high school in Jakarta. This study used the work teams as independent variabel and school culture as the dependent variabel. Data analysis technique used is descriptive analysis to calculate the price of the mean, median, mode, and standard deviation. Analysis of the data to test hypotheses using simple linear regression analysis to determine the percentage and degree of influence of variable $X$ to variable $\mathrm{Y}$ used the coefficient of determination. In this research, principals of state senior high school has been choosen as a unit analysis and there were 91 samples of state senior high schools in Jakarta. The results of the research showed that work teams has a direct positive effect on school culture. The research suggested that work teams was important determinants of school culture.
\end{abstract}

Keywords: work teams, school culture, senior high school

\section{Introduction}

Education has a very important role in the life of nation and state, it is a barometer of nation's life quality. On the other hand, education is the plot of nation's journey heading on a civilization that is desired by all of humanity who can generate cultural values [1]. Education is an effort to encourage all components of society to be committed and consistent in developing Indonesia's education world [2].

In addition, an effective work team in the organization needs ongoing cooperation and commitment to assume the collective responsibility in completing its duties, so that an effective work team has confidence and optimistic culture on beliefs to be able to achieve success [3]

Related to the improvement of schools, the school culture becomes one of the most neglected[4]. Regard to these problems, that the school culture is one of the most complex and important concepts in education because it is the heart of the school culture and becomes something that is hard to understand and modify. The basic essence of an organisation's culture to be, the deeper level of basic assumptions and beliefs that are shared by members of an organisation, that operate unconsciously, and that define in a basic 'taken-for-granted' fashion an organisation's view of itself and its environment [5]. 
The school culture also becomes important because school culture is determined by the values, shared beliefs, and behavior of the various stakeholders within the school's community and reflects the school's social norm [6].

\section{Related Works}

In some schools that have relatively the same resources, the same background of principals and teachers but they have different school culture values, their achievements can be different [7]. These differences can be influenced by understanding and compliance of school's community to the norms, values, and beliefs that are upheld. The stronger belief and compliance of community to the norms and values, the higher attachment to the school, so the greater sense of belonging, and the more powerful motives of their studies [8].

School culture is defined as the basic assumptions, norm, and values, and cultural artifacts that are shared by school members, which influence their functioning at school [9]. School culture as collection of tradisions and rituals that have been built up over time as teachers, students, parents, and administrators work together and deal with crises and accomplishments [10]. Further explained that a school culture may be defined as guiding beliefs and expectations evident in the way a school operates. To change a school culture and create a more inclusive school, educators must question their belief about teaching and learning for students who struggle to learn and engage in a collaborative change process that results in new values, beliefs, norms, and preferred behaviors [11]. Based on the description, it was concluded that school culture is defined as the formation of habits which become a set of guidelines that are formed over time that have mutually agreed of visions and goals. There are four (4) indicators to identify the school culture, namely; values, norms, traditions and rituals, beliefs and convictions

Teams are group of two or more people who people who interact and influence one another, are mutually accountable for achieving common associated with organizational objectives, and perceive themselves as a social entity within an organization [12]. Work team consist of a small number of people with complementary skills who hold themselves mutually accountable for pursuing a common purpose, achieving performance goals, and improving interdependent work processes [13]. A work team, a group whose individual efforts result in performance that is greater than the sum of the individual inputs [14]. So the work team defined as a group of people who work together to produce greater performance, with indicators; have the same goals, shared responsibilities, application of skills, interact, and interdependent.

State Senior High School in the Entire DKI Jakarta, Indonesia need to pay attention to the importance of building a school atmosphere. The atmosphere that cozy and fun class as well as building relationships that support the harmonious establishment of norms, values, beliefs, attitudes, characters, and achievement motivation can push the growing attitude of positive thinking in school community, though in fact, this often does not appear on the cultural development program that may affect the value of culture it own.

\section{Method}

The method used in this study was a quantitative approach through a survey method with causal techniques. The hypothesis testing of this study used simple linear regression analysis with constellation model between variables [15], consisted of two variables, i.e. exogenous variable; work team $(\mathrm{X})$, and endogenous variable; school culture $(\mathrm{Y})$. 
Simple linear regression analysis used to measure the effect of independent variable (X) and dependent variable (Y). The simple regression analysis is as follows:

$$
Y=\alpha+\beta X
$$

Criteria for acceptance and rejection of the hypothesis if:

$\mathrm{t}_{\text {count }}>\mathrm{t}_{\text {table }}$, or significant $\leq 0.05, \mathrm{H}_{0}$ was rijected and $\mathrm{H}_{1}$ was accepted

$\mathrm{t}_{\text {count }} \leq \mathrm{t}_{\text {table }}$, or significant $>0.05, \mathrm{H}_{0}$ was accepted and $\mathrm{H}_{1}$ was rijected

Calculates the percentage of the effect of variable $\mathrm{X}$ on $\mathrm{Y}$ by finding the coefficient of determination $\left(R_{2}\right)$. The coefficient of determination $\left(R_{2}\right)$ then provides information on the extent of regression model ability to explain the variation of the dependent variable model

\section{Results}

Based on the result of the simple linear regression analysis calculation among variables that were found in general, there was an influence of exogenous variables on endogenous variables. Meanwhile the hypothesis testing showed that the hypothesis proposed in this study generally proven the simple linear regression analysis had positively affected.

\subsection{Testing of Data Analysis Requirements}

Description of team work is known to mean $=169.32$, median $=170$, mode $=178$, standard deviation $=8.13$, minimum score $=151$, maximum score $=185$, variance $=66.13$, range $=34$, and sum $=15408$.

Description of school culture known to mean $=16.18$, median $=160$, mode $=164$, standard deviation $=9.16$, minimum score $=139$, maximum score $=180$, variance $=83.88$, range $=41$, and $\operatorname{sum}=14576$.

\subsection{Regression Statistics}

The adjusted $\mathrm{R}$ square shows the percentage of the dependent variable that can be explained or influenced by the independent variable. The results of the analysis show that adjusted $\mathrm{R}$ square is 0.1757 , which means that $18 \%$ variation or changes in the difference in operating results can be explained by variations or changes in the team work. While the remaining $82 \%$ is explained by other variables outside the model.

\subsection{Normality Test Error Data of Regression Appraisal School Culture on Work Team (Y on X)}

Table 1. Results of Normality Test

\begin{tabular}{cccccc}
\hline \multirow{2}{*}{$\begin{array}{c}\text { Error of Regression } \\
\text { Appraisal }\end{array}$} & N & Lcount & \multicolumn{2}{c}{ Ltable } & \multirow{2}{*}{ Conclusion } \\
\cline { 4 - 5 } & 91 & 0,0604 & 0,0929 & 0,108 & Normally Distributed \\
\hline Y on X & $9=\mathbf{5 \%}$ & $\boldsymbol{\alpha}=\mathbf{1 \%}$ & \\
\hline
\end{tabular}

Based on the results of the Liliefors statistic calculation, it was known that the normality for error appraisal $\mathrm{Y}$ on $\mathrm{X}$ obtained $\mathrm{L}_{\text {count }}$ of 0,0604 . The Liliefors critical value of $\mathrm{L}_{\text {table }}$ for $\mathrm{n}=$ 91 on $\alpha=0,05$ was 0,0929 . From those results, it was known that $\mathrm{L}_{\text {count }}\left(\mathrm{L}_{0}\right) \leq \mathrm{L}_{\text {table }}\left(\mathrm{L}_{t}\right)$, then $\mathrm{H}_{0}$ was accepted, i.e data sources from populations that was normally distributed, it means that 
analysis requirements have been fulfilled. The interpretation was the parametric test requirements for work team variable has been fulfilled and the data can be processed further, so it can be concluded that the distribution of error appraisal School Culture (Y) on Work Team (X) came from populations that has normal distribution.

\subsection{Significance Test and Linear Equation of Regression School Culture on Work Team (Y on X)}

Table 2. ANAVA for Significance Test and Linear Equation of Regression $\widehat{\mathbf{Y}}=$

\begin{tabular}{|c|c|c|c|c|c|c|}
\hline \multirow{3}{*}{$\begin{array}{l}\text { Source of } \\
\text { Variants }\end{array}$} & \multirow{3}{*}{ Dk } & \multicolumn{3}{|c|}{$80,24+0,472 X$} & \multirow{2}{*}{\multicolumn{2}{|c|}{$F_{\text {table }}$}} \\
\hline & & $\boldsymbol{U}$ & DUV & $\Gamma$ & & \\
\hline & & & & & $\alpha=0,05$ & $\alpha=\mathbf{0 , 0 1}$ \\
\hline Total & 91 & 4950 & & & & \\
\hline Regression a & 1 & 2334722,8 & & & & \\
\hline Regression $\mathrm{b} / \mathrm{a}$ & 1 & 1326,59 & 1326,56 & $18,97 * *$ & 3,95 & 6,93 \\
\hline Residual & 89 & 9614,28 & 96,92 & & & \\
\hline \multirow[t]{2}{*}{ Error } & 22 & 1273,08 & 57,87 & $0,783^{\text {ns }}$ & 1,7 & 2,12 \\
\hline & 67 & 4949,51 & 73,87 & & & \\
\hline
\end{tabular}

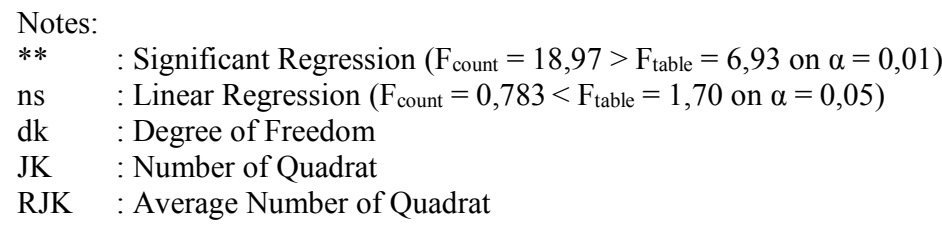

The regression equation was $\widehat{\mathrm{Y}}=80,24+0,472 \mathrm{X}$, for significance test obtained $\mathrm{F}_{\text {count }}$ of 18,97 was higher than $F_{\text {table }}(0,01 ; 1: 89)$ of 6,93 on $\alpha=0,01$. Because $F_{\text {count }}>F_{\text {table }}$ then the regression equation was stated to be very significant. For linear test obtained $F_{\text {count }}$ of 0,783 was smaller than $F_{\text {table }}(0,05 ; 22: 67)$ of 1,70 on $\alpha=0,05$. Because $F_{\text {count }}<F_{\text {table }}$ then the scatter plot estimated which forms a linear line can be accepted. The scatter plot was approaching the line of regression equations which linear estimated visually can be seen in the following figure: 


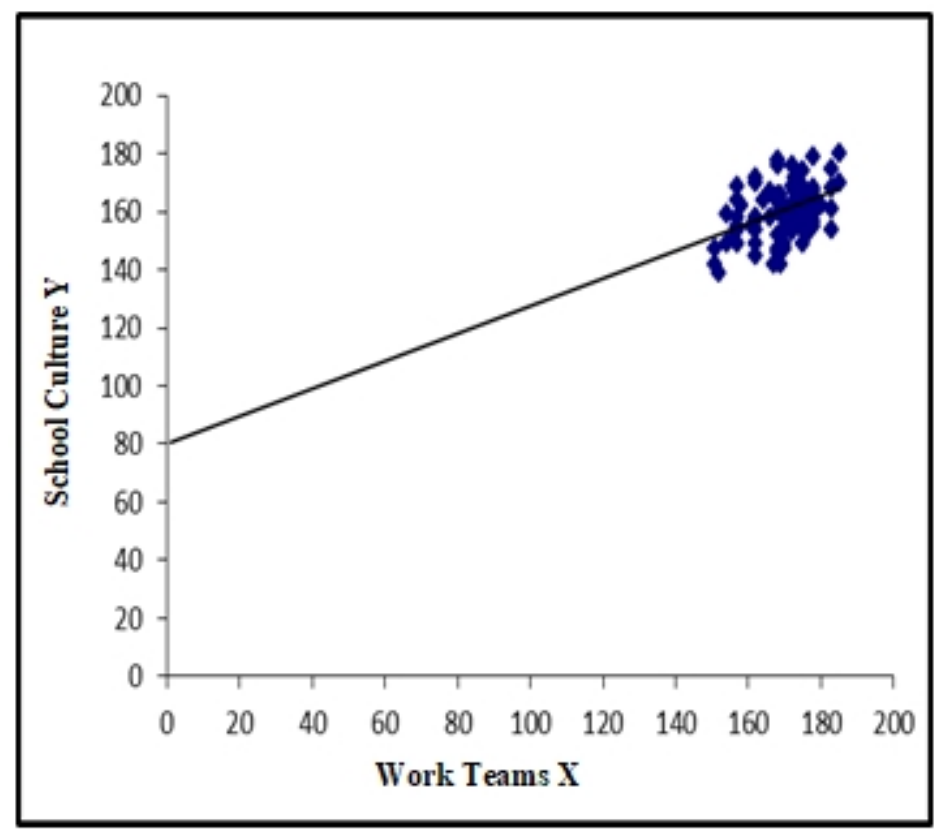

Fig. 1. The Regression Equation Graph $\widehat{\mathbf{Y}}=80,24+0,472 \mathrm{X}$

\subsection{Hypothesis Testing}

The statistical hypothesis which tested, there was positively influenced of Work Team (X) on School Culture (Y).

Statistically:

$$
\begin{aligned}
& \mathrm{H}_{0}: \beta y \leq 0 \\
& \mathrm{H}_{1}: \beta \mathrm{y}>0
\end{aligned}
$$

Based on the result analysis in the influence of Work Team (X) on School Culture (Y) obtained the coefficient is 0.419 with $t_{\text {count }}=4,36$, while the value of $t_{\text {table }}=1,99(\alpha=0,05$; $\mathrm{dk}=89$ ). Therefore $t_{\text {count }}>\mathrm{t}_{\mathrm{tabl}}$, then $\mathrm{H}_{0}$ was rejected, $\mathrm{H}_{1}$ was accepted. Thus it can be concluded that Work Team has positively influenced on School Culture.

\section{Discussion}

The results of the study show that the school culture will increase if it is supported by a stronger work team. This is because school culture will influence the perception of the principal towards the school, where the perception will be the basis for developing the attitude and behavior of the principal. The effort that can be made is to create a school culture that has strong character that has an impact on improving the work team. School culture is values that are believed to be appropriate and can realize school goals. So that the school culture is always maintained and developed by the principal and the school community as a tradition.

School culture is the belief and attitude influencing every aspect of how a school functions. Culture shared by all school stakeholders makes the actualization of both short-and 
long-term objectives easier. In this context, the best practices for shaping school culture for professional educators are personal mastery, team learning, and building a shared vision [16]. Instructional leaders can use school culture as a tool to influence and lead by establishing coordination among stakeholders, having a direct impact on student achievement [17] .

In a school, share beliefs and informal norms among teachers have a significant impact on behavior. Culture provides members with a commitment to beliefs and values beyond themselves; individuals belong to a group that is larger than themselves. When the culture is strong, so is their identification with the group and the influence of the group [18].

\section{Conclusion}

Based on the result of the analysis and hypothesis testing, it showed that Work Team had a significant influence on School Culture. It means that the higher quality of work team felt by the principal, then would be better the School Culture. Instead, the weaker of work team felt by the principal, then would be lower the School Culture in State Senior High Schools in DKI Jakarta. This was as stated that adjusting school culture and work teams can identify highquality solutions to problems that arise at school. That leads to kindness communication and hence to improve school performance. This can reduce the problem with maximize flexibility and responsiveness to student demands [19].

The effort made by the schools were to improve a good or positive work team so that the school had better teaching and learning activities an effective work team should had the same goals and needed support systems to get a chance of success if it maintained and facilitated by the organization. In this case there was active work team participation in harmony with school strategies that required a school culture that respected the process so that it could be survived in the organization.

Acknowledgment. This research would not have been possible without the support of all parties and support from DKI Jakarta government. As well as all members of my Dissertation Committee and professional guidance from promotor and co-promotor. I also don't forget to thank all those who have helped this research and other related parties.

\section{References}

[1] K. Y. Tung, Simphoni Sedih Pendidikan Nasional. Jakarta: Abdi Tandur, 2002.

[2] Muhardi, "Kontribusi Pendidikan Dalam Meningkatkan Kualitas Bangsa Indonesia," Mimbar, vol. XX, no. 4, pp. 478-492, 2004.

[3] S. R. Manzoor, H. Ullah, M. Hussain, and Z. M. Ahmad, "Effect of Teamwork on Employee Performance," Int. J. Learn. Dev., vol. 1, no. 1, pp. 110-126, 2011.

[4] A. Azizollah, F. Abolghasem, and D. Mohammad Amin, "The Relationship Between Organizational Culture and Organizational Commitment in Zahedan University of Medical Sciences," Glob. J. Health Sci., vol. 8, no. 7, p. 195, 2016.

[5] S. Louise, "School culture," Cambridge Companion to Mod. Japanese Cult., no. 9, pp. 92-112, 2009.

[6] D. Carpenter, "School culture and leadership of professional learning communities," Int. J. Educ. Manag., vol. 29, no. 5, pp. 682-694, 2015.

[7] R. Cleveland, J. Chambers, C. Mainus, N. Powell, and R. Skepple, "School culture, equity, and student academic performance in a rural Appalachian school," Kentucky J. Excell. Coll. Teach. Learn., vol. 9, no. 2011, pp. 35-42, 2012.

[8] Pusat Pengembangan Tenaga Kependidikan, Manajemen Sekolah dan Kepemimpinan 
Sekolah. Depok: Kampus Pusbangtendik, 2015.

[9] R. Maslowski, Culture and School Performance Phd Thesis. 2001.

[10] K. D. Peterson and T. E. Deal, "How Leaders Influence the Culture of Schools // Kent D. Peterson and Terrence E. Deal," vol. 56, no. 1, pp. 28-30, 1998.

[11] N. L. Waldron and J. McLeskey, "Establishing a collaborative school culture through comprehensive school reform," J. Educ. Psychol. Consult., vol. 20, no. 1, pp. 58-74, 2010.

[12] V. G. McShane, Organizational Behavior: Organizational Contexts. Singapore: McGraw-Hill/Irwin, 2015.

[13] Chuck Williams, Management. Mason: South-Western Cengage Learning, 2009.

[14] T. A. J. Stephen P. Robbins, Organizational Behavior. England: Pearson Education Limited, 2017.

[15] S. Hadi, Metodologi Research 2. Yokyakarta: Yayasan Penerbitan Fakultas Psikologi UGM, 2002.

[16] G. E. H. and S. M. Hord, Implementing change patterns, principles, and potholes, 4th ed. New York: Person Education, 2015.

[17] J. Lewis, J. Asberry, G. Dejarnett, and G. King, "The Best Practices for Shaping School Culture for Instructional Leaders," Alabama J. Educ. Leadersh., vol. 3, pp. 5763, 2016.

[18] W. K. H. and C. G. Miskel, , Educational Administration, New York: , 2005. New York: McGraw-Hill/Irwin, 2005.

[19] N. D. Manju and G. Sheela, "Work Culture of Teachers in Relation to their Gender, Type of School and Experience," vol. 2, no. 3, pp. 52-59, 2013. 